U.S. DEPARTMENT OF ENERGY

OFFICE OF INSPECTOR GENERAL

\title{
AUDIT OF THE FEDERAL ENERGY REGULATORY \\ COMMISSION LEASED WAREHOUSE SPACE
}

\section{MASTER}

DISTRIBUTION OF THS DOCUMENT IS UNLMMTES $8 \mathrm{~s}$

Report Number: CR-B-96-01

Capital Regional Audit Office

Date of Issue: May 24, 1996

Germantown, MD 20874 


\section{DISCLAMMER}

Portions of this document may be illegible in electronic image products. Images are produced from the best available original document. 


\section{AUDIT OF THE FEDERAL ENERGY REGULATORY}

COMMISSION LEASED WAREHOUSE SPACE

\section{TABLE OF CONTENTS}

Page

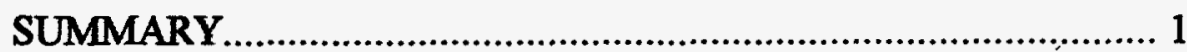

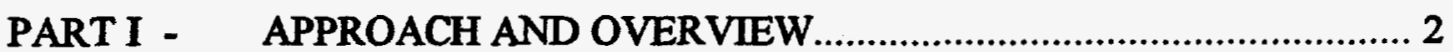

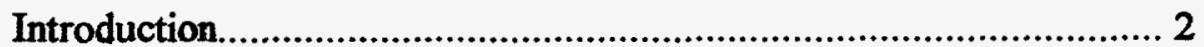

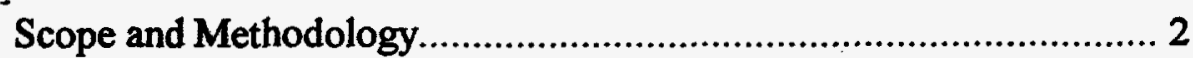

Observations and Conclusions........................................................ 2

PART II - FINDING AND RECOMMENDATIONS........................................ 4

Minimizing Warehouse Space................................................................ 4

PART III - MANAGEMENT AND AUDITOR COMMENTS........................... 7 


\section{U.S. DEPARTMENT OF ENERGY \\ OFFICE OF INSPECTOR GENERAL \\ OFFICE OF AUDIT SERVICES}

\section{AUDIT OF THE FEDERAL ENERGY REGULATORY COMMISSION LEASED WAREHOUSE SPACE}

Audit Report Number: CR-B-96-01

\section{SUMMARY}

The Federal Energy Regulatory Commission (Commission) stores furniture, automated data processing equipment, and office supplies in a warehouse located in Landover, Maryland. The annual operating cost for this space $(25,830$ square feet) approximates $\$ 455,000--\$ 245,000$ in lease costs and $\$ 210,000$ for contractor personnel. The purpose of the audit was to assess the effectiveness of the Commission's use of warehouse space. The specific audit objective was to determine whether the Commission was minimizing the need for warehouse space for the storage of office supplies, furniture, and equipment.

Federal Property Management Regulations and prudent business practices require Government agencies to minimize their need for space. More space was being leased than needed because Commission officials understood that they were obligated by terms of the lease to pay for the space until March 31,2002. We found, however, that there was a misunderstanding by officials, and that the Commission could at any time relinquish warehouse space by giving 120 days notice. Because of this misunderstanding and the recent relocation of the Commission to a newly furnished facility, about 16,000 square feet of warehouse space was being used to store furniture and equipment that was no longer needed by the Commission. An additional 6,000 square feet of space was used to store office supplies instead of using a more frequent ordering program that would reduce space.requirements.

We recommended that the Commission reduce the need for warehouse space by excessing unneeded furniture and equipment and reducing the storage of office supplies. We also recommended that the Commission renegotiate the contract in order to reduce contractor staff used to operate the warehouse to reflect the reduction of its operations.

Commission management plans to reduce warehouse space by 15,830 square feet and retain 10,000 square feet and is reviewing alternatives and options for expediting their excessing of property. Further, the Commission plans to reduce the storage of office supplies by adopting a more frequent ordering program and plans to renegotiate the warehouse support contract after the space is relinquished.

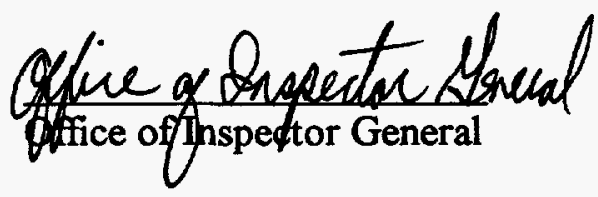




\section{PART I}

\section{APPROACH AND OVERV.IEW}

\section{INTRODUCTION}

On April 1, 1992, the Federal Energy Regulatory Commission (Commission) leased 25,830 square feet of warehouse space from the General Services Administration (GSA). At the time of the review, about 6 years remained on the initial 10-year lease. Also, costs to lease and operate this space were about $\$ 455,000$ a year.

The purpose of the audit was to assess the effectiveness of the Commission's use of warehouse space. The audit objective was to determine whether the Commission was minimizing the need for warehouse space for the storage of furniture, equipment, and office supplies.

\section{SCOPE AND METHODOLOGY}

The audit was performed from December 1995 through April 1996 at the Commission's headquarters in Washington, D.C. and at the Commission's warehouse in Landover, Maryland. Our audit work included reviews of applicable Federal and Commission regulations related to warehouse activities. In addition, we reviewed related management and internal audit reports and reports issued by the Office of Inspector General.

To achieve our objective, we (1) determined the amount of warehouse space used for furniture, equipment, and office supplies; (2) obtained a copy of and discussed the terms of the lease agreement for the warehouse; (3) discussed the benefits and limitations of the "just-in-time" supply program with Commission and GSA staff; (4) reviewed excess property reports, discussed the excessing program, and performed limited tests of internal controls over property; and (5) obtained a copy of and discussed the contract for operation of the warehouse.

The audit was made in accordance with generally accepted Government auditing standards for performance audits and included tests of internal controls and compliance with laws and regulations to the extent necessary to satisfy the audit objective. Accordingly, we assessed internal controls regarding warehouse practices and procedures. Because our review was limited, it would not necessarily have disclosed all internal control deficiencies that may have existed. We did not rely on computer-processed data to accomplish the audit objective.

An exit conference was waived by the Executive Director on May 22, 1996.

\section{OBSERVATIONS AND CONCLUSIONS}

The Commission was not minimizing the need for warehouse space. Commission officials understood that they were bound by a lease with the GSA at an annual cost of about $\$ 245,000$ 
until March 31, 2002. As a result of this understanding and the recent relocation to a newly furnished facility, about 16,000 square feet of warehouse space was used to store excess furniture and equipment. In addition, about 6,000 square feet of space.was used to store an inventory. of office supplies instead of utilizing a more frequent ordering program that would reduce space requirements. We found that the Commission, by giving a 120-day notice, could relinquish warehouse space thereby saving leasing costs. Additional savings could be achieved by adjusting the ordering and delivery program and reducing the contractor staff in proportion to the reduced warehouse operations. Further, other organizations could benefit by utilizing the excess property in the warehouse.

Part II of this report provides details on our finding and recommendations. Part III of this report includes detailed management and auditor comments. 


\title{
PART II
}

\section{FINDING AND RECOMMENDATIONS}

\author{
Minimizing Warehouse Space
}

\section{FINDING}

Federal Property Management Regulations require Government agencies to continuously review their space requirements and minimize the need for space. The Commission was leasing more warehouse space than needed. About 16,000 square feet of warehouse space was used to store excess furniture and automated data processing equipment, and another 6,000 square feet was used to store office supplies instead of utilizing a more frequent ordering program that would reduce space requirements. Commission officials understood from discussions with the GSA that they were obligated for the annual lease costs until March 31, 2002. We found that there was a misunderstanding by officials, and that the Commission could relinquish warehouse space by giving 120 days notice. About $\$ 1$ million in lease costs could be saved by relinquishing the vacated space. Additional savings could be achieved by reducing the office supplies inventory and reducing the contractor staff in proportion to the reduced warehouse operations. Further, other organizations could benefit by utilizing the excess property in the warehouse.

\section{RECOMMENDATIONS}

We recommend that the Execuitive Director, Federal Energy Regulatory Commission, take action to:

1. Minimize the need for warehouse space by disposing of excess property and utilizing a more frequent ordering program for office supplies.

2. Relinquish vacated warehouse space.

3. Renegotiate the contract in order to adjust warehouse contractor staff in proportion to the reduction in warehouse operations.

\section{MANAGEMENT REACTION}

The Executive Director concurred with the recommendations. Plans are underway to expedite excessing of property and to implement an ordering process through the GSA Customer Service Center program that will make deliveries within 72 hours for office supplies. Once the current stock of supplies is depleted and the backlog of excess property is cleared out, 15,830 square feet of warehouse space will be relinquished. Further, once the warehouse space has been relinquished, the administrative support contract will be renegotiated. 


\section{DETAILS OF FINDING}

The Federal Property Management Regulations establish policies and procedures for agencies to follow in managing and operating warehouses. Agencies are required to continuously review their needs for space and relinquish unneeded space. The amount of space should be limited to what is needed to accomplish their programs, and space no longer needed should be considered excess. These regulations also prescribe property management practices that limit the amount of property on hand to what is needed to accomplish their programs.

\section{WAREHOUSE OPERATIONS}

The Commission was not minimizing the need for warehouse space. About 16,000 square feet of this warehouse space was being used to store unneeded furniture and equipment, and about 6,000 square feet of this space was used to store office supplies. Although the Commission recognized that the 25,830 square feet of space was more than needed, it understood it was required to pay the annual lease cost of about $\$ 245,000$ whether or not the space was used. A prior internal management study dated February 1994 identified excess warehouse space leased by the Commission. The study recommended reducing the warehouse space after excessing unneeded furniture and equipment and implementing a "just-in-time" delivery program for office supplies. The Commission did not implement these recommendations due to the understanding that they were obligated to pay for the leased space until March 31, 2002.

The Commission used about 22,000 square feet of the warehouse space to store excess furniture, equipment, and office supplies. Six thousand of the 22,000 square feet of the space was used to warehouse office supplies although GSA had a more frequent delivery program that was available to Government agencies. The program provides office supplies and other items directly to the ordering office within 72 hours of order placement thus reducing the need for agencies to warehouse these items.

The Commission employed five full-time contractor personnel to operate the warehouse: a truck driver, a receiving clerk, two warehouse specialists, and a warehouse manager. The cost to maintain this staff was about $\$ 210,000$ annually.

\section{JUSTIFICATION FOR WAREHOUSE RETENTION}

Commission officials informed us that they had met with GSA in September 1993 to discuss reducing the amount of its leased warehouse space. As a result of this meeting, officials understood that if they wanted to eliminate part or all of the warehouse space, the Commission would be obligated to pay for the space until another tenant could be found. During the audit, we discussed this issue with GSA and found that there was a misunderstanding concerning the leasing of the space. According to GSA officials, unneeded warehouse space could be relinquished at any time after giving a 120-day written notice. The notice would give a description of the area involved, its location, and the estimated date of release. However, GSA advised that there had to be a feasible break of space to avoid sharing of space. 


\section{IMPACT ON WAREHOUSE OPERATIONS}

Reducing the size of the warehouse operation would reduce costs for the Commission. We calculated that disposing of unneeded furniture and equipment would free up about 16,000 square feet of warehouse space. Also, some of the 6,000 square feet of space used for the storage of office supplies would be available when the supplies were used up after a more frequent ordering program was adopted. When this space is vacated, action should be taken to identify total warehouse space requirements and relinquish unneeded space. About $\$ 1$ million in lease costs would be saved if the vacated space is relinquished no later than April 1, 1997. Further, savings would be achieved if the Commission renegotiated its contract for personnel used to operate the warehouse in proportion to the amount of space that is relinquished. In addition, other organizations could benefit by utilizing the excess property in the warehouse. 


\section{PART III}

\section{MANAGEMENT AND AUDITOR COMMENTS}

In response to this report, the Executive Director, Federal Energy Regulatory Commission, concurred with the recommendations. A summary of management's comments and our response follows.

Recommendation 1. Minimize the need for warehouse space by disposing of excess property and utilizing a more frequent ordering program for office supplies.

Management Comments. Concur in principle. Management stated that they intend to clear out the backlog of excess furniture and equipment and, in addition to using GSA's excessing program, are in the process of reviewing alternatives and options for expediting their excess program. Management also intends to discontinue warehousing a 3-month stock level of supplies and implement an ordering process through the GSA Customer Service Center program that makes delivery within 72 hours. However, management believes that for items that cannot be purchased through CSC/GSA, it is more cost effective to purchase in bulk. Therefore, some warehouse space will be retained for these bulk items. Even though a "just-in-time" delivery system is designed to support a decentralized ordering program, the Commission's ordering program will be centralized. Management believes that by ordering on a more frequent basis, the warehouse space can still be reduced.

Auditor Comments. Management comments are responsive to the recommendation.

Recommendation 2. Relinquish vacated warehouse space.

Management Comments. Concur in principle. Management agreed to relinquish 15,830 square feet of space once the current stock of supplies is depleted and the backlog of excess equipment is cleared out. The remaining 10,000 square feet will be used for paper and supplies (3,000 square feet), computer depot ( 3,000 square feet), furniture (1,500 square feet), in-transit items ( 800 square feet), office space ( 500 square feet), and circulating space (1,200 square feet).

Management did not agree with the estimated savings in lease costs, as they want to complete negotiations for space requirements prior to determining the actual savings.

Auditor Comments. Management comments are responsive to the recommendation.

Recommendation 3 . Renegotiate the support services contract in order to adjust warehouse contractor staff in proportion to the reduction.

Management Comments. Concur in principle. Management stated they will renegotiate the administrative support contract once the warehouse space has been relinquished. 
IG Report No. CR-B-96-01

\section{CUSTOMER RESPONSE FORM}

The Office of Inspector General has a continuing interest in improving the usefulness of its products. We wish to make our reports as responsive as possible to our customers' requirements, and, therefore, ask that that you consider sharing your thoughts with us. On the back of this form, you may suggest improvements to enhance the effectiveness of future reports. Please include answers to the following questions if they are applicable to you:

1. What additional background information about the selection, scheduling, scope, or procedures of the audit would have been helpful to the reader in understanding this report?

2. What additional information related to findings and recommendations could have been included in this report to assist management in implementing corrective actions?

3. What format, stylistic, or organizational changes might have made this report's overall message more clear to the reader?

4. What additional actions could the Office of Inspector General have taken on the issues discussed in this report which would have been helpful?

Please include your name and telephone number so that we may contact you should we have any questions about your comments.

Name

Date

Telephone

Organization

When you have completed this form, you may telefax it to the Office of Inspector General at (202) 586-0948, or you may mail it to:

\section{Office of Inspector General (IG-1) \\ Department of Energy \\ Washington, DC 20585}

ATTN: Customer Relations

If you wish to discuss this report or your comments with a staff member of the Office of Inspector General, please contact Wilma Slaughter at (202) 586-1924. 